\title{
Impact of Deficit Irrigation on Maize Physical and Chemical Properties and Ethanol Yield
}

\author{
Liman Liu, ${ }^{1}$ Norman Klocke, ${ }^{2}$ Shuping Yan, ${ }^{3}$ Danny Rogers, ${ }^{1}$ Alan Schlegel,${ }^{4}$ Freddie Lamm, ${ }^{5}$ \\ Shing I. Chang, ${ }^{6}$ and Donghai Wang ${ }^{1,7}$
}

\begin{abstract}
The objective of this research was to study the effect of irrigation levels (five levels from 102 to $457 \mathrm{~mm}$ of water) on the physical and chemical properties and ethanol fermentation performance of maize. Twenty maize samples with two crop rotation systems, grain sorghum-maize and maize-maize, were harvested in 2011 and evaluated at the Kansas State University Southwest Research-Extension Center near Garden City, Kansas, under a semiarid climate. Results showed that maize kernel weight, density, and breakage susceptibility decreased as irrigation level decreased. Starch contents of maize samples grown under a low irrigation level were approximately $3.0 \%$ lower than those under a high irrigation level. Protein contents ranged from 9.24 to $11.30 \%$ and increased as irrigation level decreased. Maize flour thermal and rheological properties were analyzed by differential scanning calorimetry and the Micro Visco-
\end{abstract}

ABSTRACT

Cereal Chem. 90(5):453-462
Amylo-Graph-U device. Starch gelatinization temperature increased significantly as irrigation level decreased, whereas starch pasting viscosity decreased as irrigation level decreased. Free amino nitrogen (FAN) was significantly affected by irrigation level: it increased as irrigation decreased. Ethanol fermentation efficiency ranged from 90.96 to $92.48 \%$ and was positively correlated with FAN during the first $32 \mathrm{~h}$ of fermentation $\left(r^{2}=0.645\right)$. Deficit irrigation had a negative impact on ethanol yield. The maize with lower irrigation yielded about $4.0 \%$ less ethanol (44.14 $\mathrm{mL} / 100 \mathrm{~g}$ of maize) than maize with high irrigation $(45.92 \mathrm{~mL} / 100 \mathrm{~g}$ of maize). Residual starch contents in the distillers dried grains with solubles were in a range of $0.80-1.02 \%$. In conclusion, deficit irrigation had a significant effect on physical properties, chemical composition, ethanol yield, and fermentation efficiency of maize.
Irrigated agriculture is the primary user of water resources globally and consumes $70-80 \%$ of total diverted water in the arid and semiarid zones (Fereres and Soriano 2007). Irrigated agriculture used more than $70 \%$ of the water withdrawn from the Earth's rivers (Heng 2002). Crop production is highly dependent on water availability, and any shortage has a significant impact on final yields (Kirda 2002; Tognetti et al 2006; Quiroga et al 2011); however, water is a finite resource for which competition is increasing among agricultural, industrial, and domestic sectors. Meeting increased demand for food production and food security with less water availability is a great challenge.

With reduced water resources available for agriculture, scientists and engineers have developed innovative technologies such as deficit irrigation programs aimed at increasing efficient use of irrigation water (Kirda 2002; Tognetti et al 2006; Fereres and Soriano 2007). Water deficits during a specific crop development period significantly affect crop yield (metric tons per hectare); therefore, the yield response to water stress has been studied extensively. Previous research reported that grain yields (metric tons per hectare) decreased as irrigation level decreased (Kirda et al 2005; Fereres and Soriano 2007; Ayana 2011). Pandey et al (2000) studied the effect of deficit irrigation and nitrogen on maize and found that grain yield reduction was proportional to

\footnotetext{
* The $e$-Xtra logo stands for "electronic extra" and indicates that Figures 1-3 and 6-8 appear in color online.

${ }^{1}$ Department of Biological and Agricultural Engineering, Kansas State University, Manhattan, KS 66506, U.S.A.

${ }^{2}$ Southwest Research-Extension Center, Kansas State University, Garden City, KS 67846, U.S.A.

${ }^{3}$ C. W. Brabender Instruments, Inc., South Hackensack, NJ 07606, U.S.A.

${ }^{4}$ Southwest Research-Extension Center, Kansas State University, Tribune, KS 67879, U.S.A.

${ }^{5}$ Northwest Research-Extension Center, Kansas State University, Colby City, KS 67701, U.S.A.

${ }^{6}$ Industrial and Manufacturing Systems Engineering, Kansas State University, Manhattan, KS 66506, U.S.A.

${ }^{7}$ Corresponding author. Phone: (785) 532-2919. Fax: (785) 532-5825. E-mail: dwang@ksu.edu
}

http://dx.doi.org/10.1094/CCHEM-07-12-0079-R

(c) 2013 AACC International, Inc. duration of deficit irrigation. Because maize is an important irrigated crop, field research has been conducted on maize over years to study the relationship between irrigation and yields. Klocke et al (2007) studied yield and irrigation for maize in 1986-1998 in west central Nebraska and found that $90 \%$ of full irrigation grain yields could be gained by applying only $47 \%$ of full irrigation. Klocke et al (2011) conducted a field study of fully irrigated to deficit-irrigated maize in 2005-2009 in southwest Kansas and reported that yield variability increased as irrigation decreased, illustrating a greater income risk with less irrigation.

As water resources continue to decline, deficit irrigation is becoming an important strategy for minimizing agricultural water use. Limited or deficit irrigation may significantly affect not only crop yields but also grain quality and end uses; however, little attention has been paid to the effects on grain quality and end-use quality, such as in the area of ethanol production.

Maize is the number one crop produced in the United States in terms of land area and annual production. Maize is widely used for livestock feed, ethanol production, and food production. The U.S. Department of Agriculture reported in 2010 that feed and residual use accounted for 121,717 thousand metric tons of maize and industrial ethanol accounted for 127,533 thousand metric tons of maize, which was the number one use for maize in that year (U.S. Grains Council 2011). According to the World Agricultural Supply and Demand Estimates of the USDA (2012), 5 billion bushels of maize from the 2011-2012 crop year was used for ethanol and by-products. Maize grain qualities are important and greatly affect end-use product qualities. Some research has been done on grain sorghum to study the effect of irrigation on grain quality and ethanol yield (Wu et al 2008; Miller and Ottman 2010), but little research has been conducted on maize. The objective of this research was to study the effect of deficit irrigation on the physical and chemical properties and ethanol fermentation performance of maize.

\section{MATERIALS AND METHODS}

\section{Cropping System and Irrigation Protocol}

Twenty maize samples were grown in a five-year rotation of maize-maize-wheat-sorghum-sunflower (maize-maize) and sunflower-maize-maize-wheat-sorghum (GS-maize) starting in 2005 
and continuing through 2011 (Table I). GS-maize and maize-maize samples treated with five irrigation levels $(457,356,254,178$, and $102 \mathrm{~mm}$ of water) were evaluated for physical and chemical properties and ethanol fermentation performance. The prior year's irrigation treatment effects carried over to the same irrigation treatment in the following year. Each crop was present every year in five cropping blocks, which were replicated over the five years. The irrigation variable was achieved by increasing the number of days between irrigation events rather than applying a percentage of full irrigation during each irrigation event. The irrigation treatment protocol was designed to include operational constraints of commercial center-pivot irrigation systems in the Great Plains region, where pumping capacities limit the frequency of irrigation events. Cultural practices, hybrid selections, planting techniques, and fertilizer and herbicide applications were the same across irrigation treatments and followed the requirements of no-till management (Klocke et al 2011). This research was conducted at the Kansas State University Southwest Research-Extension Center near Garden City, Kansas. The climate is semiarid, with long-term average annual precipitation of $477 \mathrm{~mm}$, mean summer growing season daytime high temperature of $29^{\circ} \mathrm{C}$ (30 year average May through August), open-pan evaporation (April through September) of 1,810 $\mathrm{mm}$, and a frost-free period of 170 days. During the study, average annual precipitation was $495 \mathrm{~mm}$.

\section{Sample Preparation}

All samples were screened with a Gamet sieve shaker (Dean Gamet Manufacturing, Minneapolis, MN, U.S.A.) with a 6.35 $\mathrm{mm}$ screen and were hand cleaned to remove large foreign materials. For ethanol fermentation, the cleaned samples were ground into fine flour by passing through a $0.5 \mathrm{~mm}$ screen on a UDY cyclone mill (UDY Corporation, Fort Collins, CO, U.S.A.).

\section{Physical Properties of Maize Kernels}

Maize density was determined with an air-comparison pycnometer (model MVP-1, Quantachrome Corporation, Syosset, NY, U.S.A.), as described by Pomeranz et al (1984). Kernel breakage susceptibility was tested with a Stein breakage tester (model CK2) following AACC International Approved Method 55-20.01. The 1,000-kernel weights were obtained from the kernel weight of 1,000 whole, sound kernels. Maize test weight was determined by AACCI Approved Method 55-10.01.

Microstructures of maize endosperm were examined with a Hitachi S-3500N scanning electron microscope (SEM) with an S-6542 absorbed electron detector (Hitachinaka, Ibaraki, Japan). Samples were coated with $4 \mathrm{~nm}$ of a $60 \%$ gold and $40 \%$ palladium mixture in a Denton vacuum chamber (Desk II, Moorestown, NJ, U.S.A.) before SEM examination. Images were taken from enlarged floury endosperm with 500× magnification.

\section{Chemical Composition of Maize}

Total starch was analyzed following AACCI Approved Method 76-13.01. Crude protein, fat, and ash were analyzed following AOAC approved methods 990.03, 920.39 (corresponding to AACCI Approved Method 30-20.01), and 942.05 (corresponding

TABLE I

Crop Rotation Used in This Study

\begin{tabular}{lll}
\hline Crop Year & \multicolumn{1}{c}{ GS-Maize } & \multicolumn{1}{c}{ Maize-Maize } \\
\hline $2005-2006$ & sunflower-maize & maize-maize \\
$2006-2007$ & maize-maize & maize-wheat \\
$2007-2008$ & maize-wheat & wheat-sorghum \\
$2008-2009$ & wheat-sorghum & sorghum-sunflower \\
$2009-2010$ & sorghum-sunflower & sunflower-maize \\
$2010-2011$ & sunflower-maize & maize-maize \\
\hline
\end{tabular}

${ }^{\mathrm{z}}$ Maize used in this study was the second crop listed for the 2010-2011 crop year. GS = grain sorghum. to AACCI Approved Method 08-03.01), respectively (AOAC International 1999), and crude fiber was analyzed with the A200 filter bug technique (Ankom Technology 2006). Free amino nitrogen (FAN) was determined through the European Brewery Convention method (EBC 1987) with modification. Around $150 \mathrm{mg}$ of maize flour was mixed with $1.5 \mathrm{~mL}$ of deionized distilled water in a $2.5 \mathrm{~mL}$ microcentrifuge tube, vortexed five times in $10 \mathrm{~min}$, and then centrifuged at $10,644 \times g$ for $20 \mathrm{~min}$. An aliquot of 1.0 $\mathrm{mL}$ of supernatant was diluted with $4.0 \mathrm{~mL}$ of distilled water; it then was ready for FAN analysis.

\section{Thermal Properties}

Thermal properties were analyzed with a TA DSC Q200 instrument. Five samples with different irrigation levels were selected from each GS-maize and maize-maize samples. Maize samples were weighed accurately $(\approx 5-8 \mathrm{mg}$ ) into stainless steel pans with a microbalance. Deionized distilled water was added carefully with a micropipette into the sample pan. The weight ratio of water to dry flour was 2:1. The pans were sealed and allowed to rest overnight at room temperature. An empty sealed pan was used as a reference. Samples were characterized in an inert environment that used nitrogen with a gas flow rate of $50 \mathrm{~mL} / \mathrm{min}$ and were heated from 0 to $140^{\circ} \mathrm{C}$ at a heating rate of $10^{\circ} \mathrm{C} / \mathrm{min}$. Enthalpies are reported on a dry flour weight basis. Onset temperature $\left(T_{\mathrm{o}}\right)$, peak temperature $\left(T_{\mathrm{p}}\right)$, conclusion temperature $\left(T_{\mathrm{c}}\right)$, and enthalpy of gelatinization $\left(\Delta H_{\mathrm{gel}}\right)$ were calculated.

\section{Pasting Properties}

A Brabender Micro Visco-Amylo-Graph-U device (model 803222, Brabender GmbH \& Co. KG, Duisburg, Germany) was used to test pasting properties of maize flour. Five samples with different irrigation levels were selected from each GS-maize and maize-maize samples. Ten grams of flour (14\% moisture content) and $105 \mathrm{~g}$ of distilled water were mixed in the testing bowl at room temperature; the slurry was heated from 30 to $95^{\circ} \mathrm{C}$ at the heating rate of $8.0^{\circ} \mathrm{C} / \mathrm{min}$; then the hot paste was held at $95^{\circ} \mathrm{C}$ for $5 \mathrm{~min}$, cooled to $30^{\circ} \mathrm{C}$ at the cooling rate of $8.0^{\circ} \mathrm{C} / \mathrm{min}$, and held at $30^{\circ} \mathrm{C}$ for $1 \mathrm{~min}$. The total process took $22 \mathrm{~min} 16 \mathrm{sec}$. The test speed of the stirrer was at $300 \mathrm{rpm}$, and the measurement sensitivity range was at $250 \mathrm{cmg}$.

\section{Ethanol Fermentation}

Whole maize flour with moisture content in a range of 6.48 $7.67 \%$ (30.00 g, dry mass) was weighed into a clean $250 \mathrm{~mL}$ Erlenmeyer flask and was mixed with $100 \mathrm{~mL}$ of preheated (around $60-70^{\circ} \mathrm{C}$ ) enzyme solution containing $0.1 \mathrm{~g}$ of $\mathrm{KH}_{2} \mathrm{PO}_{4}$ and $20 \mu \mathrm{L}$ of Liquozyme $\alpha$-amylase (Novozymes, Franklinton, NC, U.S.A.). Samples were evenly wetted and thoroughly suspended. Flasks were transferred to a $70^{\circ} \mathrm{C}$ rotary water-bath shaker operating at around $180 \mathrm{rpm}$. The temperature of the water bath was raised to $90^{\circ} \mathrm{C}$ for about $30 \mathrm{~min}$ and then lowered to $86^{\circ} \mathrm{C}$ and kept at that temperature for $60 \mathrm{~min}$. Flasks were removed from the water-bath shaker. Material sticking on the inner surface of the flasks was pushed back into the mashes with a spatula. The inner surface and spatula were rinsed with $3-5 \mathrm{~mL}$ of distilled water. After the mashes cooled down to room temperature $\left(\approx 25-30^{\circ} \mathrm{C}\right)$, the $\mathrm{pH}$ of the mashes was adjusted to around 4.2 with $2 \mathrm{~N} \mathrm{HCl}$.

Before the simultaneous saccharification and fermentation process, the dry yeast was activated by adding $1.0 \mathrm{~g}$ of active dry yeast into $19 \mathrm{~mL}$ of preculture broth (containing $20 \mathrm{~g}$ of glucose, $5.0 \mathrm{~g}$ of peptone, $3.0 \mathrm{~g}$ of yeast extract, $1.0 \mathrm{~g}$ of $\mathrm{KH}_{2} \mathrm{PO}_{4}$, and $0.5 \mathrm{~g}$ of $\mathrm{MgSO}_{4} \cdot 7 \mathrm{H}_{2} \mathrm{O}$ per liter) and incubated in an incubator at $38^{\circ} \mathrm{C}$ for around $30 \mathrm{~min}$ at $200 \mathrm{rpm}$.

An aliquot of $1.0 \mathrm{~mL}$ of activated yeast culture, $100 \mu \mathrm{L}$ of Spirizyme glucoamylase (Novozymes), and $0.30 \mathrm{~g}$ of yeast extract were added into each flask. Flasks were sealed with an S-airlock filled with mineral oil. Fermentation was conducted at $30^{\circ} \mathrm{C}$ in an incubator shaker operating at $150 \mathrm{rpm}$ for $72 \mathrm{~h}$. The fermentation was 
monitored by measuring weight loss resulting from evolution of $\mathrm{CO}_{2}$ during fermentation $\left(\mathrm{C}_{6} \mathrm{H}_{12} \mathrm{O}_{6} \rightarrow 2 \mathrm{C}_{2} \mathrm{H}_{6} \mathrm{O}+2 \mathrm{CO}_{2} \uparrow\right)$ at 4,8 , $18,24,32,44,56$, and $72 \mathrm{~h}$ of fermentation.

After $72 \mathrm{~h}$ of fermentation, finished mash was transferred to a $500 \mathrm{~mL}$ distillation flask. The Erlenmeyer flask was washed with $100 \mathrm{~mL}$ of distilled water. Two drops of antifoam agent (Antifoam 204, a mixture of organic polyether dispersions, Sigma-Aldrich, St. Louis, MO, U.S.A.) were added to the distillation flask before the flask was placed on the heating unit to prevent foaming during distillation. The distillates were collected into a $100 \mathrm{~mL}$ volumetric flask immersed in ice water. When the distillates in the volumetric flask approaching the $100 \mathrm{~mL}$ mark $(\approx 99 \mathrm{~mL})$, the volumetric flask was removed from the distillation unit. The distillates in the volumetric flask were equilibrated for a few hours in a $25^{\circ} \mathrm{C}$ water bath. The ethanol concentration was determined by HPLC following the

TABLE II

Physical Properties of Maize Samples ${ }^{y}$

\begin{tabular}{lcccc}
\hline $\begin{array}{l}\text { Irrigation } \\
\text { Level }^{\mathbf{z}}\end{array}$ & $\begin{array}{c}\mathbf{1 , 0 0 0 - K e r n e l} \\
\text { Weight } \mathbf{( g )}\end{array}$ & $\begin{array}{c}\text { Breakage } \\
(\mathbf{\%})\end{array}$ & $\begin{array}{c}\text { Test Weight } \\
\left(\mathbf{g} / \mathbf{c m}^{\mathbf{3}}\right)\end{array}$ & $\begin{array}{c}\text { True Density } \\
\left(\mathbf{g} / \mathbf{c m}^{\mathbf{3}}\right)\end{array}$ \\
\hline GS-maize & & & & \\
1 & $329.85 \mathrm{a}$ & $7.70 \mathrm{a}$ & $0.805 \mathrm{a}$ & $1.322 \mathrm{a}$ \\
2 & $318.85 \mathrm{~b}$ & $7.72 \mathrm{a}$ & $0.803 \mathrm{a}$ & $1.318 \mathrm{~b}$ \\
3 & $228.65 \mathrm{f}$ & $2.94 \mathrm{~d}$ & $0.790 \mathrm{bc}$ & $1.304 \mathrm{c}$ \\
4 & $273.85 \mathrm{~d}$ & $6.22 \mathrm{~b}$ & $0.787 \mathrm{c}$ & $1.300 \mathrm{~d}$ \\
5 & $258.50 \mathrm{e}$ & $5.96 \mathrm{~b}$ & $0.762 \mathrm{~d}$ & $1.292 \mathrm{e}$ \\
Maize-maize & & & & \\
1 & $320.15 \mathrm{ab}$ & $5.70 \mathrm{bc}$ & $0.809 \mathrm{a}$ & $1.321 \mathrm{a}$ \\
2 & $312.65 \mathrm{~b}$ & $6.06 \mathrm{~b}$ & $0.806 \mathrm{a}$ & $1.318 \mathrm{~b}$ \\
3 & $261.40 \mathrm{e}$ & $3.47 \mathrm{~d}$ & $0.797 \mathrm{~b}$ & $1.308 \mathrm{c}$ \\
4 & $272.70 \mathrm{~d}$ & $5.13 \mathrm{c}$ & $0.795 \mathrm{~b}$ & $1.307 \mathrm{c}$ \\
5 & $286.50 \mathrm{c}$ & $5.20 \mathrm{c}$ & $0.790 \mathrm{bc}$ & $1.309 \mathrm{c}$ \\
\hline
\end{tabular}

${ }^{\mathrm{y}}$ Means in the same column followed by different letters indicate significant differences $(P<0.05)$.

${ }^{\mathrm{z}}$ Levels: $1=$ high and $5=$ low. GS $=$ grain sorghum; see Table $\mathrm{I}$ for a full description of the crop rotations.
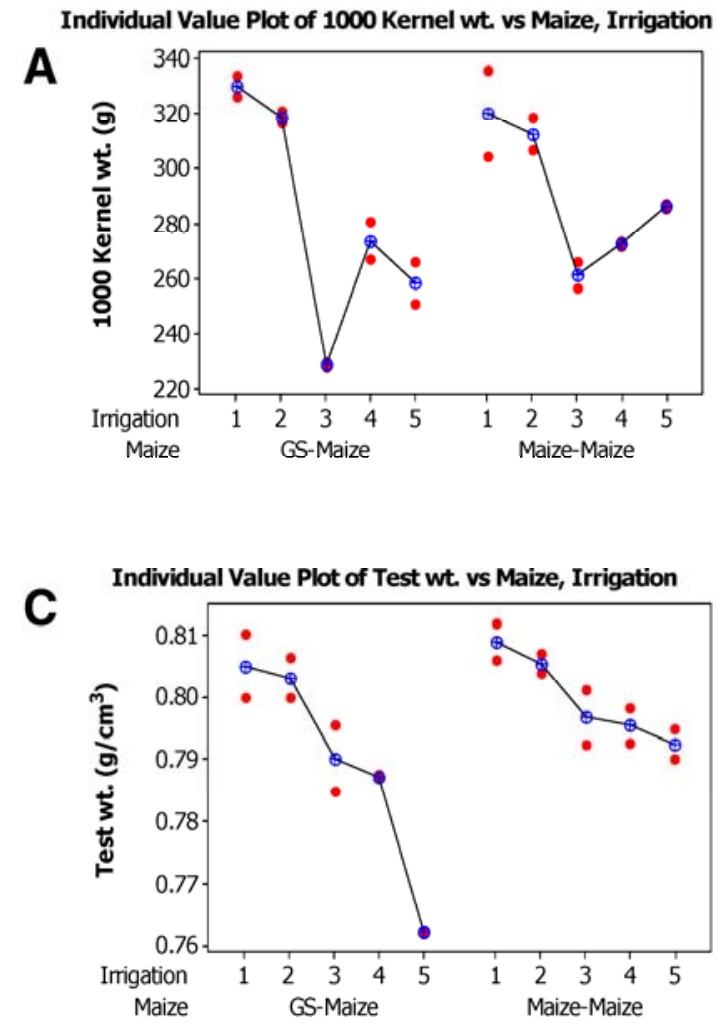

method described by Wu et al (2006). Fermentation efficiencies were calculated as the actual ethanol yield divided by the theoretical ethanol yield. The theoretical ethanol yield was determined from the total starch contents in the samples, assuming $0.5672 \mathrm{~g}$ of ethanol from $1 \mathrm{~g}$ of starch (Thomas et al 1996).

\section{Statistical Analysis}

A randomized complete block design (RCBD) was conducted with the experimental variable irrigation level (five levels) and the block variable crop rotation (two rotations). Because we were mainly interested in the variable irrigation level, the variable crop rotation was treated as the block or nuisance variable. Under this RCBD experimental plan, each factor combination was repeated twice. The statistical model for the RCBD can be written in the following model:

$$
y_{i j k}=\mu+\tau_{i}+\beta_{j}+\epsilon_{i j} ; i=1,2, \ldots, 5 ; j=1,2 ; \text { and } k=2
$$

where $y_{i j}$ is one of the response variables, $\tau_{i}$ is the effect of irrigation level $i, \beta_{j}$ is the block effect of crop rotation $j, \in_{i j} \sim N\left(0, \sigma^{2}\right)$ is the random error term with a constant variance $\sigma^{2}$, and $k$ is the two replicates of each sample. The analysis of variance was done with Minitab statistical software version 16 (Minitab, State College, PA, U.S.A.). Pearson correlation coefficients for the relationships between all response variables were also calculated with the same software.

\section{RESULTS AND DISCUSSION}

\section{Effects on Physical Properties and Chemical Composition of Maize Samples}

Weights of 1,000 kernels ranged from 228.65 to $329.85 \mathrm{~g}$ among GS-maize samples and from 261.40 to $320.15 \mathrm{~g}$ among maize-maize samples (Table II). Maize samples treated with low irrigation levels showed significantly lower 1,000-kernel weight,
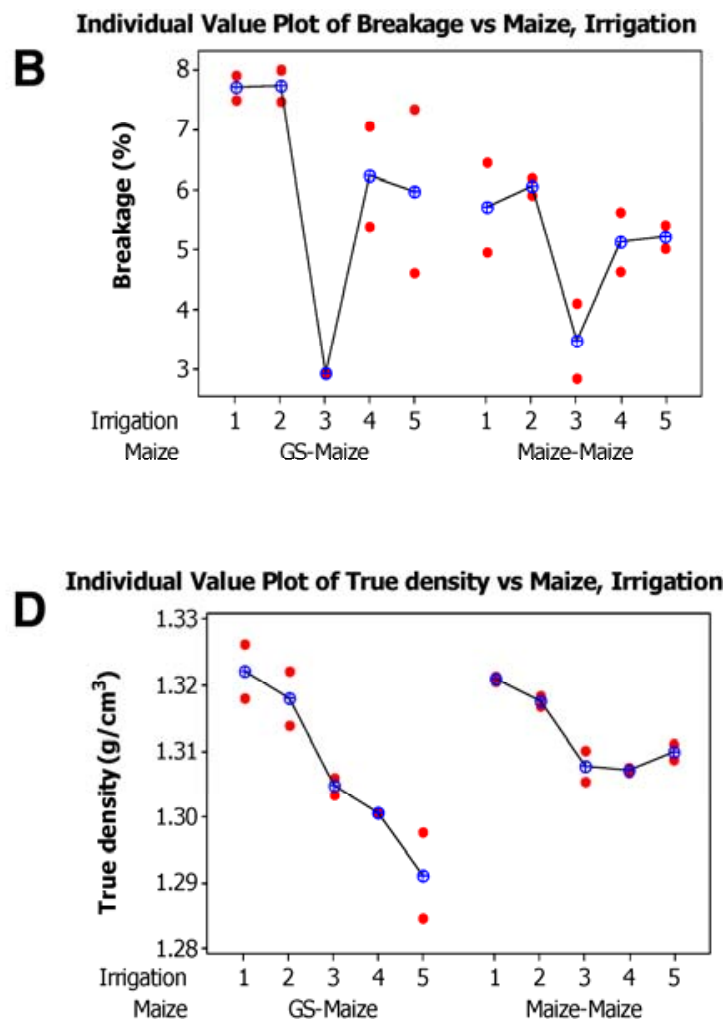

Fig. 1. Physical properties for maize grown in different rotations and irrigation levels (two-way ANOVA; $P<0.05$ ). A, 1,000-kernel weight; B, breakage; $\mathbf{C}$, test weight; and D, true density $(\bullet=$ two observations; $\oplus=$ mean value $)$. Irrigation level: $1=$ highest and $5=$ lowest. GS = grain sorghum; see Table I for a full description of the crop rotations. 
whereas the lowest 1,000-kernel weight was found in the maize treatment with the medium irrigation level (Fig. 1A). Breakage susceptibility was in the range of 2.94 to $7.72 \%$ among GS-maize samples and 3.47 to $6.06 \%$ among maize-maize samples (Table II). Maize with high irrigation level had the highest breakage susceptibility (Fig. 1B), which agreed with previous studies in maize (Bauer and Carter 1986; Kniep and Mason 1989). Kernel breakage susceptibility was based on the corneous-to-floury endosperm ratios. Typically, the ratio of corneous-to-floury endosperm is about 2 to 1 in dent maize (Wolf et al 1952). Maize with low amounts of corneous endosperm appears to be soft and easily damaged during handling (Paulsen et al 1983). Grain grown under drought conditions would have higher kernel hardness (Taylor et al 1997; Weightman et al 2008), meaning higher corneous-to-floury endosperm ratios, which tend to be more resistant to breakage. Maize's 1,000 -kernel weight was significantly $(P<0.0001)$ correlated with breakage susceptibility (Table III), which is opposite the results reported by Peplinski et al (1992), that maize with low breakage susceptibility had the highest 100-kernel weight, and Pomeranz et al (1986), that little effect of kernel weight was found on breakage susceptibility. This difference is probably because the previous studies used different maize varieties. Test weight ranged from 0.762 to $0.805 \mathrm{~g} / \mathrm{cm}^{3}$ among GS-maize samples and from 0.790 to $0.809 \mathrm{~g} / \mathrm{cm}^{3}$ among maize-maize samples (Table II). All the maize test weights fell into a high-test-weight category based on the results described by Paulsen and Hill (1985) and Peplinski et al (1992), which is higher than U.S. no. 1 grade maize $(0.72$ $\mathrm{g} / \mathrm{cm}^{3}$ ). Maize samples treated with low irrigation levels had significantly lower test weight than those treated with high irrigation levels (Fig. 1C), which was in agreement with results reported by Griess et al (2010) for sorghum grain. True density of maize samples decreased as irrigation level decreased (Fig. 1D), which was in contrast with research on sorghum (Griess et al 2010). No rela- tionship between kernel density and breakage susceptibility was found, which agreed with some previous studies (Bauer and Carter 1986; Kniep and Mason 1989). Crop rotation had a significant effect on maize test weight and true density (Fig. 1C and D). For maize-maize rotation, the grain test weight and true density did not keep decreasing, as was the trend of GS-maize rotation, when irrigation level decreased from level 3 to levels 4 and 5. Kernel weight $(P<0.001)$ and density $(P<0.0001)$ were positively correlated with starch contents but strongly and negatively $(P<0.0001)$ correlated with protein contents (Table III). Kernel test weight and true density were positively associated with grain yield (Kaye et al 2007). Ethanol yield was greatly affected by kernel test weight and true density $(P<0.0001)$ (Table III), which agreed with the effects of irrigation level on ethanol yield.

Starch contents of maize samples grown under a low irrigation level were approximately $3.0 \%$ lower than those under a high irrigation level (Table IV and Fig. 2A). Griess et al (2010) reported similar results for grain sorghum, in which starch concentration under irrigated conditions was significantly higher than under dryland conditions. Figure 3 shows a strong linear relationship between total starch contents and ethanol yield $\left(r^{2}=0.86\right.$, $P<0.0001$ ), which agrees with previous research reported by $\mathrm{Wu}$ et al (2008), Lacerenza et al (2008), and Yan et al (2011). Starch content was negatively correlated with fermentation efficiency, but the linear relationship was not strong $\left(r^{2}=0.46\right)$. Protein contents ranged from 9.24 to $11.30 \%$ among GS-maize samples and from 9.59 to $11.02 \%$ among maize-maize samples, in which the low irrigation level resulted in the highest protein content and the high irrigation level resulted in the lowest protein content (Table IV and Fig. 2B). The grain protein content was expected to be higher in the most droughtlike conditions (Guttieri et al 2000; Weightman et al 2008). Daniel and Triboï (2002) reported that an increase in temperature as well as a drought after anthesis induced

TABLE III

Pearson Correlation Coefficients Among Evaluated Parameters for 20 Maize Samples ${ }^{\mathrm{z}}$

\begin{tabular}{|c|c|c|c|c|c|c|c|c|}
\hline Parameter & $\begin{array}{c}\text { 1,000-Kernel } \\
\text { Weight }\end{array}$ & $\begin{array}{c}\text { Test } \\
\text { Weight }\end{array}$ & $\begin{array}{c}\text { True } \\
\text { Density }\end{array}$ & Breakage & $\begin{array}{c}\text { Total } \\
\text { Starch }\end{array}$ & $\begin{array}{l}\text { Crude } \\
\text { Protein }\end{array}$ & $\begin{array}{c}\text { Ethanol } \\
\text { Yield }\end{array}$ & Efficiency \\
\hline 1,000 -kernel weight & 1.000 & & $\ldots$ & $\cdots$ & $\ldots$ & $\cdots$ & $\ldots$ & $\ldots$ \\
\hline Test weight & $0.709 * * *$ & 1.000 & $\ldots$ & $\ldots$ & $\ldots$ & $\ldots$ & $\ldots$ & $\ldots$ \\
\hline True density & $0.785 * * *$ & $0.959 * * *$ & 1.000 & $\ldots$ & $\ldots$ & $\ldots$ & $\ldots$ & $\ldots$ \\
\hline Breakage & $0.719 * * *$ & 0.134 & 0.270 & 1.000 & $\ldots$ & $\ldots$ & $\ldots$ & $\ldots$ \\
\hline Total starch & $0.688 * *$ & $0.762 * * *$ & 0.820 **** & 0.345 & 1.000 & $\ldots$ & $\ldots$ & $\ldots$ \\
\hline Crude protein & $-0.758 * * *$ & $-0.725^{* * * *}$ & $-0.843^{* * * *}$ & -0.441 & $-0.889 * * *$ & 1.000 & $\ldots$ & $\ldots$ \\
\hline Ethanol yield & $0.641 *$ & $0.772 * * *$ & $0.845 * * *$ & 0.216 & $0.946 * * *$ & $-0.925 * * *$ & 1.000 & $\ldots$ \\
\hline Efficiency & -0.425 & -0.406 & -0.367 & -0.341 & $-0.618 *$ & 0.295 & -0.375 & 1.000 \\
\hline
\end{tabular}

$\mathrm{z} *, * *$, and $* * *$ indicate $P<0.05,0.001$, and 0.0001 , respectively.

TABLE IV

Chemical Composition, Ethanol Yield, and Fermentation Efficiency of Maize Samples ${ }^{\mathrm{x}}$

\begin{tabular}{|c|c|c|c|c|c|c|c|c|}
\hline \multirow{2}{*}{$\begin{array}{l}\text { Irrigation } \\
\text { Level }^{y}\end{array}$} & \multicolumn{5}{|c|}{ Chemical Composition $(\%, \mathrm{db})$} & \multirow{2}{*}{$\begin{array}{c}\text { FAN } \\
(\mathrm{mg} / \mathrm{L})\end{array}$} & \multirow{2}{*}{$\begin{array}{c}\text { Ethanol Yield } \\
(\mathbf{m L})^{\mathrm{z}}\end{array}$} & \multirow{2}{*}{$\begin{array}{l}\text { Fermentation } \\
\text { Efficiency }(\%)\end{array}$} \\
\hline & Total Starch & Crude Protein & Crude Fat & Crude Fiber & Ash & & & \\
\hline \multicolumn{9}{|l|}{ GS-maize } \\
\hline 1 & $69.45 a$ & $9.24 \mathrm{~d}$ & $3.42 \mathrm{a}$ & $1.40 \mathrm{a}$ & $1.26 \mathrm{a}$ & $36.30 \mathrm{e}$ & $45.86 a$ & $91.86 \mathrm{ab}$ \\
\hline 2 & $70.02 \mathrm{a}$ & $9.35 \mathrm{~d}$ & $3.49 \mathrm{a}$ & $1.42 \mathrm{a}$ & $1.27 \mathrm{a}$ & $36.33 \mathrm{e}$ & $45.89 \mathrm{a}$ & $91.18 b$ \\
\hline 3 & $68.03 b c$ & $10.49 \mathrm{~b}$ & $3.24 \mathrm{a}$ & $1.45 \mathrm{a}$ & $1.36 \mathrm{a}$ & $38.50 \mathrm{de}$ & $45.23 b c$ & $92.48 \mathrm{a}$ \\
\hline 4 & $66.93 d$ & $11.30 \mathrm{a}$ & $3.44 \mathrm{a}$ & $1.45 \mathrm{a}$ & $1.43 \mathrm{a}$ & $40.89 \mathrm{~cd}$ & $44.22 \mathrm{~d}$ & $91.91 b$ \\
\hline 5 & $66.46 \mathrm{~d}$ & $11.20 \mathrm{a}$ & $3.26 \mathrm{a}$ & $1.42 \mathrm{a}$ & $1.47 \mathrm{a}$ & $45.72 b$ & $44.14 d$ & $92.11 \mathrm{ab}$ \\
\hline \multicolumn{9}{|c|}{ Maize-maize } \\
\hline 1 & $69.98 \mathrm{a}$ & $9.59 \mathrm{c}$ & $3.34 \mathrm{a}$ & $1.45 \mathrm{a}$ & $1.36 \mathrm{a}$ & $39.20 \mathrm{~cd}$ & $45.76 \mathrm{ab}$ & $90.96 b c$ \\
\hline 2 & $69.82 \mathrm{a}$ & $9.76 \mathrm{c}$ & $3.31 \mathrm{a}$ & $1.38 \mathrm{a}$ & $1.28 \mathrm{a}$ & $38.56 \mathrm{~d}$ & $45.92 \mathrm{a}$ & $91.49 b$ \\
\hline 3 & $68.66 \mathrm{~b}$ & $10.70 \mathrm{~b}$ & $3.42 \mathrm{a}$ & $1.33 \mathrm{a}$ & $1.38 \mathrm{a}$ & $40.35 c$ & $45.04 \mathrm{c}$ & $91.26 \mathrm{~b}$ \\
\hline 4 & $68.12 \mathrm{c}$ & $11.02 \mathrm{a}$ & $3.40 \mathrm{a}$ & $1.40 \mathrm{a}$ & $1.42 \mathrm{a}$ & $45.12 b$ & $44.78 c$ & $91.44 b$ \\
\hline 5 & $67.38 \mathrm{~d}$ & $10.99 \mathrm{a}$ & $3.40 \mathrm{a}$ & $1.49 \mathrm{a}$ & $1.42 \mathrm{a}$ & $47.08 \mathrm{a}$ & $44.41 d$ & $91.68 \mathrm{~b}$ \\
\hline
\end{tabular}

${ }^{x}$ Means in the same column followed by different letters indicate significant differences $(P<0.05)$. FAN $=$ free amino nitrogen.

${ }^{y}$ Levels: 1 = high and $5=$ low. GS = grain sorghum; see Table I for a full description of the crop rotations.

$\mathrm{z}$ Yield in milliliters per $100 \mathrm{~g}$ of maize. 
an increase in the percentage of nitrogen from 1.78 to $2.6 \%$ in wheat grain. Protein content in the grain from the maize-maize rotation was not significantly different than the GS-maize rotation (Fig. 2B). Bryant et al (2009) reported that rice grain grown in continuous rice rotation had lower protein content than that in rice-soybean rotation. Protein content was negatively correlated with ethanol yield $(P<0.0001)$ (Table III). The reason could be that the grain kernels with higher protein content had lower accessibility of hydrolyzing enzymes to starch in the ground meal during mashing and fermentation processes, and some small starch granules may be embedded in the protein matrix (Wu et al 2008). Samples with high starch content and low protein content are a better choice for fuel ethanol production. Higher starch means higher ethanol yield, better processing efficiency, and less leftover residues after fermentation (Wu et al 2008). Starch content was positively correlated to grain yield (Griess et al 2010), whereas protein content was negatively correlated to grain yield (CalderónChinchilla et al 2008). Crude fat, fiber, and ash contents were $3.24-3.49$, 1.33-1.49, and 1.26-1.47\%, respectively (Table IV). No significant differences were found for ash, crude fat, and fiber among samples under different irrigation levels.
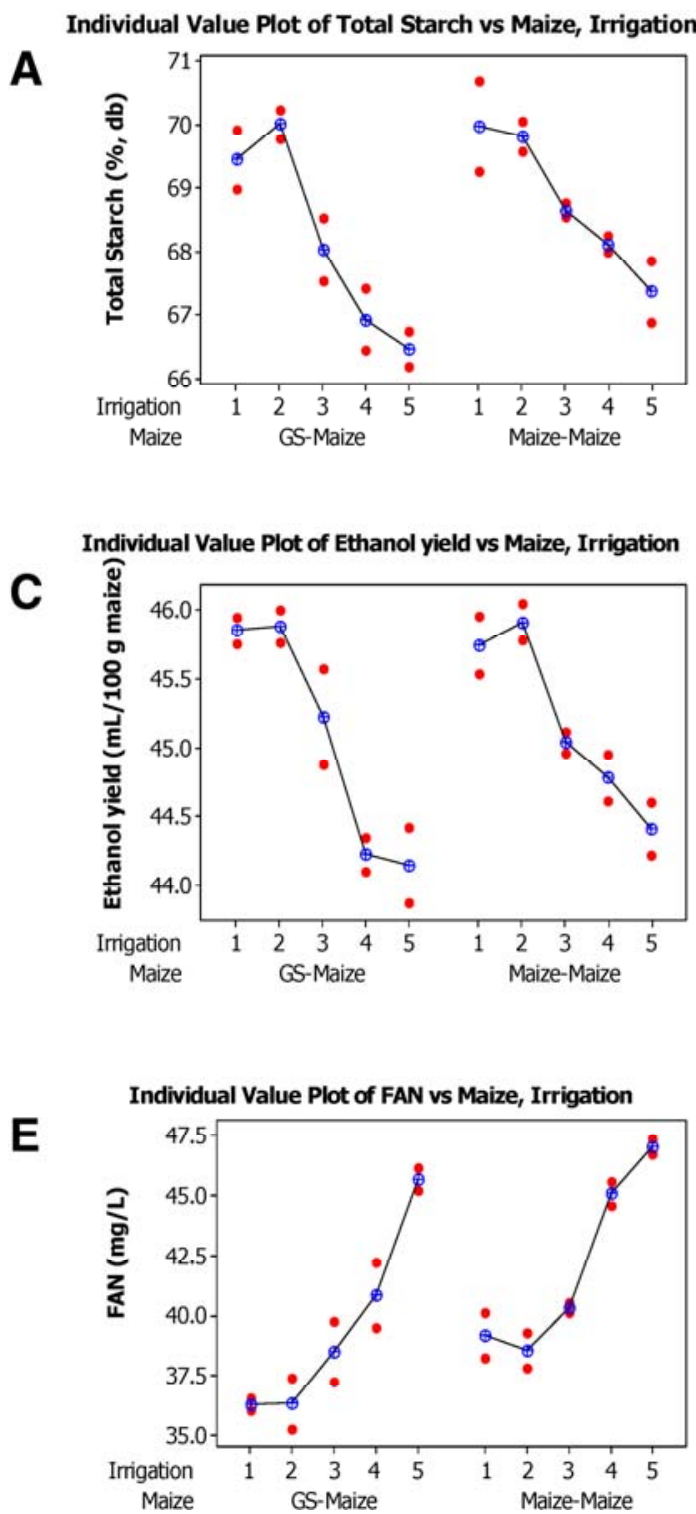

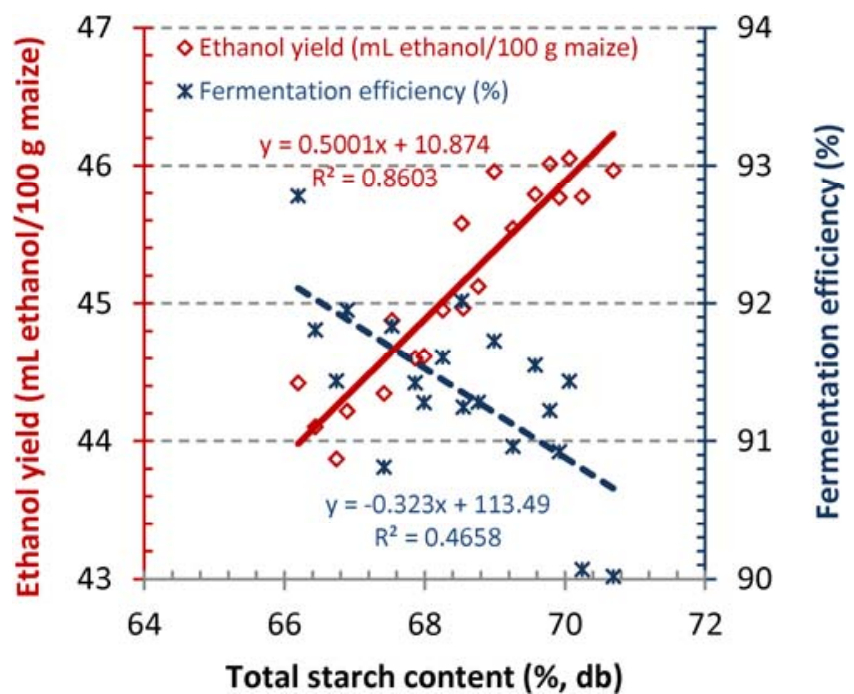

Fig. 3. Relationship between starch content of maize samples and fermentation efficiency and ethanol yield.
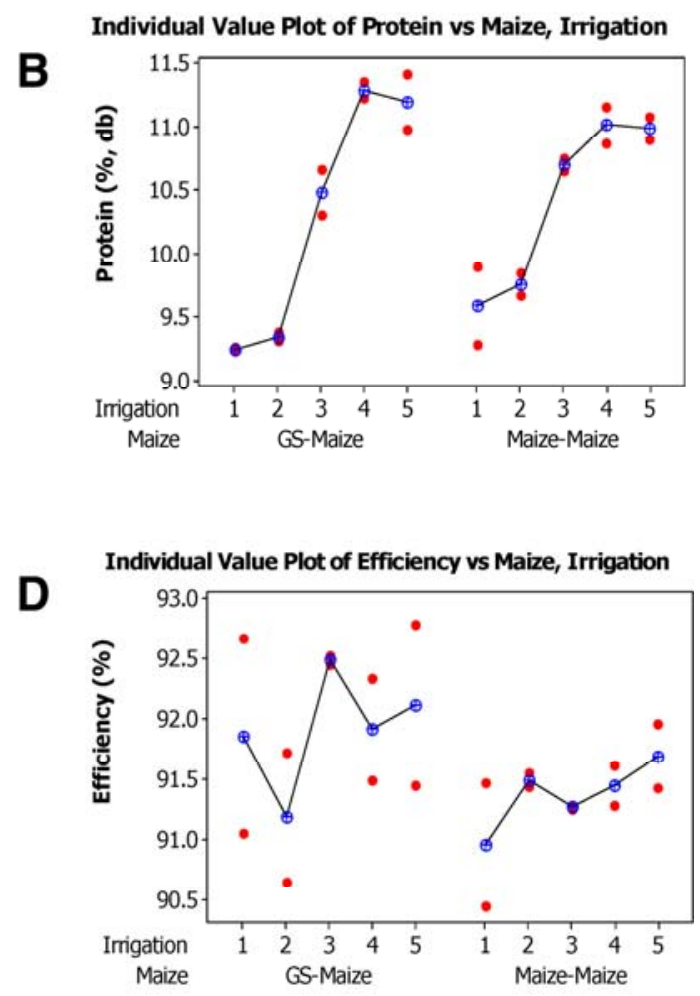

Fig. 2. Chemical composition, ethanol yield, and fermentation efficiency for maize grown in different rotations and irrigation levels (two-way ANOVA; $P<0.05)$. A, Total starch content; $\mathbf{B}$, protein content; $\mathbf{C}$, ethanol yield; D, fermentation efficiency; and $\mathbf{E}$, free amino nitrogen $($ FAN $)(\bullet=$ two observations; $\oplus=$ mean value). Irrigation level 1 = highest and 5 = lowest. GS = grain sorghum; see Table I for a full description of the crop rotations. 
The SEM images from GS-maize endosperm showed that the starch granule size of the samples with high irrigation levels was bigger than samples from low irrigation levels (Fig. 4). This result was expected, because the kernel of maize samples treated with low irrigation levels was smaller and harder than that of maize samples treated with high irrigation levels; thus, the structure of endosperm was much denser and had less space in between. The SEM image of GS-maize endosperm with irrigation level 2 (sample 217) showed more protein bodies on the surface of starch granules compared with other samples. Those protein bodies may cross-link and enmesh starch granules during mashing and block starch from exposure to hydrolyzing enzymes, which could be the reason that the fermentation efficiency of GS-maize sample 217 was significantly lower than other GS-maize samples (Table IV). Wu et al (2008) found a similar relationship in sorghum samples.

\section{Effects on Starch Thermal and Pasting Properties}

The transition temperatures $\left(T_{\mathrm{o}}, T_{\mathrm{p}}\right.$, and $\left.T_{\mathrm{c}}\right)$ and enthalpies of gelatinization $\left(\Delta H_{\text {gel }}\right)$ of the maize samples were determined by DSC. $T_{\mathrm{o}}, T_{\mathrm{p}}$, and $T_{\mathrm{c}}$ of GS-maize samples were 70.6-73.1, 76.8-
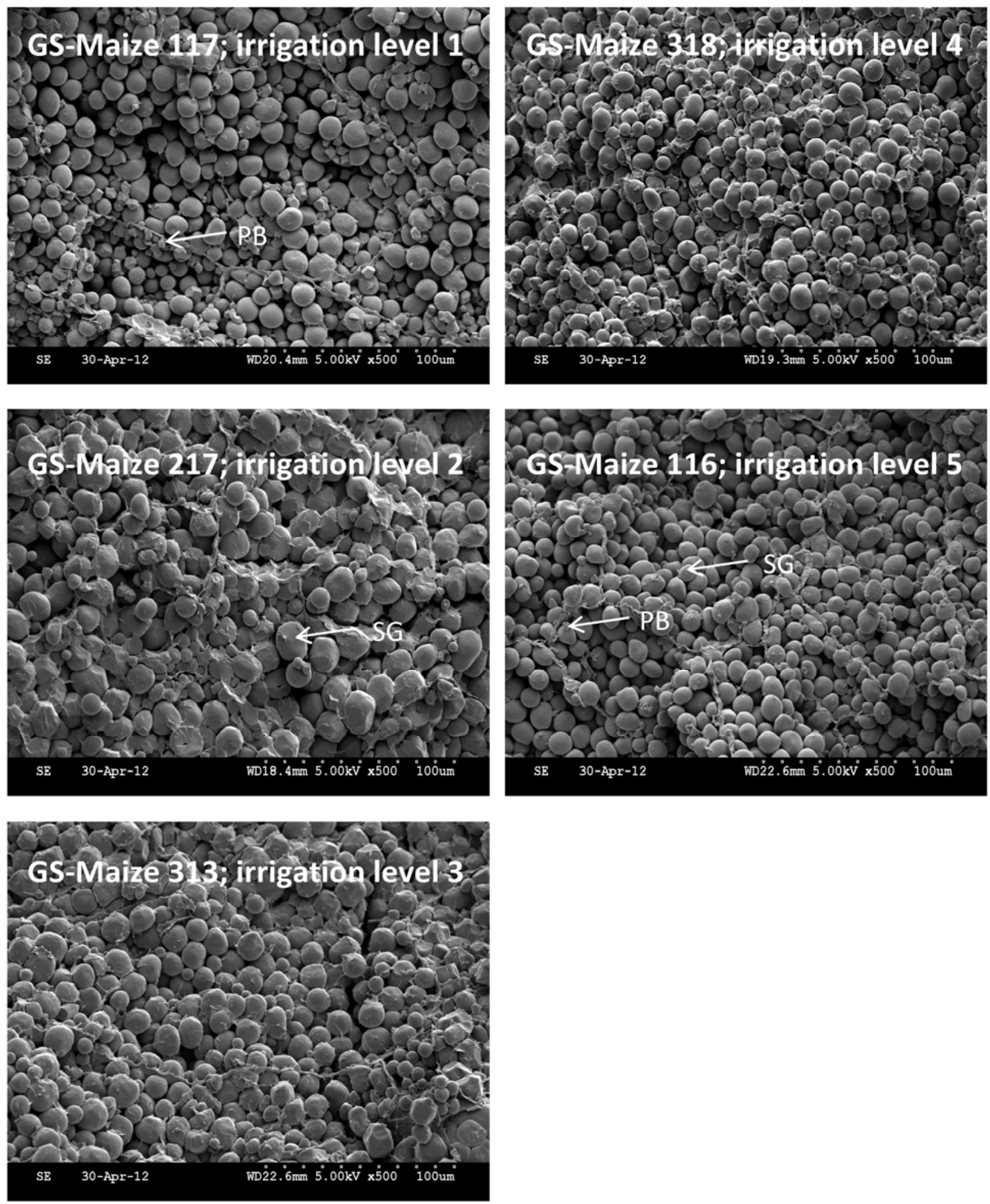

Fig. 4. Scanning electron microscopy images of starch granules and protein matrix in maize endosperm from grain sorghum (GS)-maize crop rotation kernels (irrigation level: $1=$ highest and $5=$ lowest). $\mathrm{SG}=$ starch granule, and $\mathrm{PB}=$ protein body. 

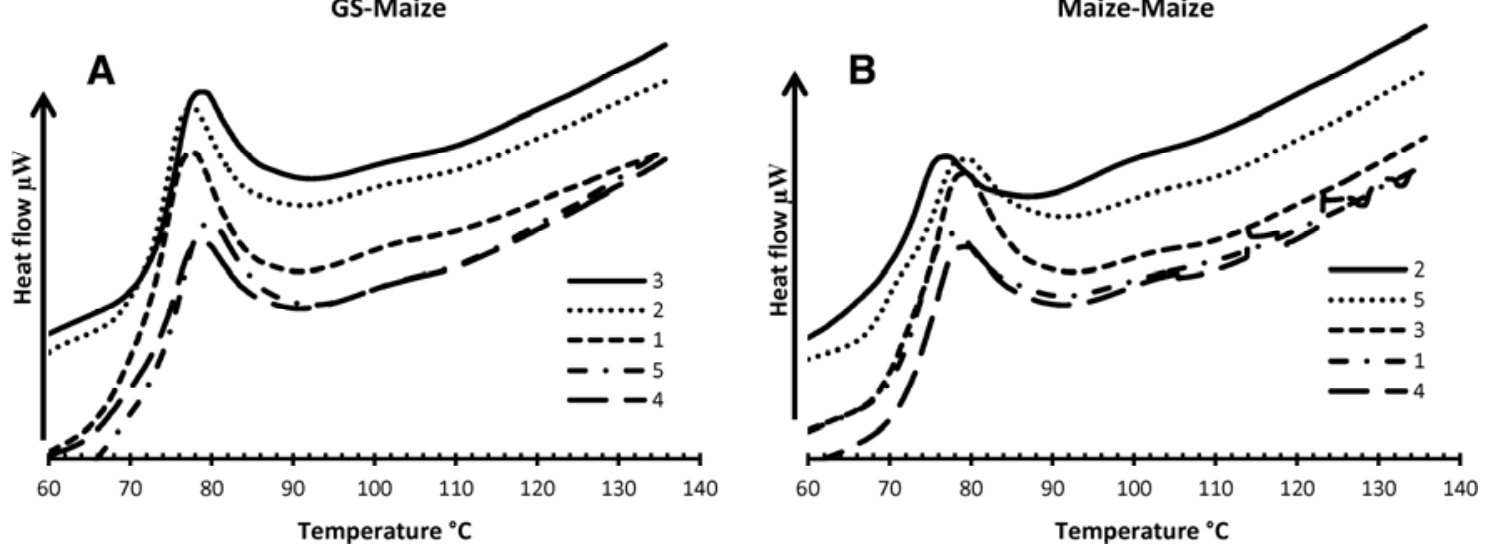

Fig. 5. A, DSC curve for grain sorghum (GS)-maize crop rotation samples from five different irrigation levels. B, DSC curve for maize-maize crop rotation samples from five different irrigation levels. Irrigation level: $1=$ highest and $5=$ lowest.

TABLE V

Starch Pasting Properties of Maize Samples ${ }^{y}$

\begin{tabular}{|c|c|c|c|c|c|c|c|}
\hline \multirow[b]{2}{*}{ Irrigation Level $^{\mathbf{z}}$} & \multirow[b]{2}{*}{ BOG $\left({ }^{\circ} \mathrm{C}\right)$} & \multicolumn{6}{|c|}{ Torque (BU) } \\
\hline & & Peak & Start of Holding & Start of Cooling & End of Cooling & Breakdown & Setback \\
\hline \multicolumn{8}{|l|}{ GS-maize } \\
\hline 1 & $73.3 \mathrm{e}$ & $162 c$ & $160 \mathrm{~b}$ & $158 \mathrm{~b}$ & $417 \mathrm{a}$ & $4.5 \mathrm{a}$ & $256.0 \mathrm{~b}$ \\
\hline 3 & $76.0 \mathrm{~b}$ & $127 \mathrm{~d}$ & $119 \mathrm{c}$ & $125 \mathrm{c}$ & $326 \mathrm{~b}$ & $2.0 \mathrm{c}$ & $201.0 \mathrm{e}$ \\
\hline 4 & $76.0 \mathrm{~b}$ & $111 \mathrm{f}$ & $102 \mathrm{~d}$ & $110 \mathrm{~d}$ & $287 \mathrm{c}$ & $1.0 \mathrm{~d}$ & $177.0 \mathrm{f}$ \\
\hline 5 & $76.5 \mathrm{a}$ & $112 \mathrm{f}$ & $108 \mathrm{~d}$ & $110 \mathrm{~d}$ & $287 \mathrm{c}$ & $1.5 \mathrm{~cd}$ & $176.5 \mathrm{f}$ \\
\hline 3 & $75.4 \mathrm{c}$ & $133 \mathrm{~d}$ & $124 \mathrm{c}$ & $132 c$ & $348 b$ & $1.0 \mathrm{~d}$ & $215.5 \mathrm{~d}$ \\
\hline 4 & $75.9 b$ & $122 \mathrm{e}$ & $115 \mathrm{c}$ & $120 \mathrm{~cd}$ & $322 b$ & $1.5 \mathrm{~cd}$ & $202.0 \mathrm{e}$ \\
\hline 5 & $75.1 \mathrm{~d}$ & $125 \mathrm{e}$ & $120 \mathrm{c}$ & $123 \mathrm{~cd}$ & $327 \mathrm{~b}$ & $2.0 \mathrm{c}$ & $203.5 \mathrm{e}$ \\
\hline
\end{tabular}

${ }^{\mathrm{y}}$ Means in the same column followed by different letters indicate significant differences $(P<0.05)$. BOG $=$ temperature at which beginning of gelatinization occurs; GS = grain sorghum; see Table I for a full description of the crop rotations.

${ }^{\mathrm{z}}$ Levels: $1=$ high and $5=$ low.

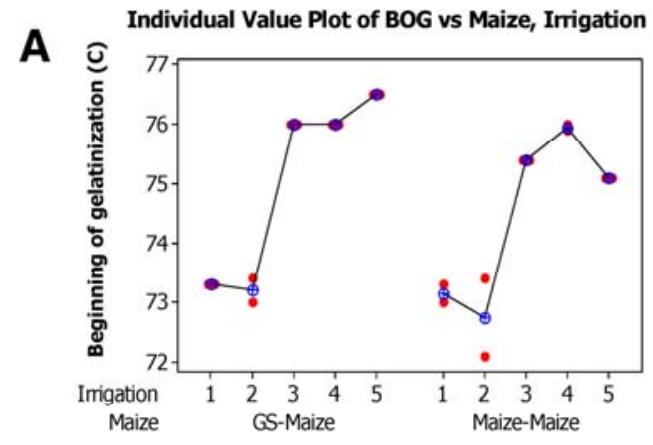

B
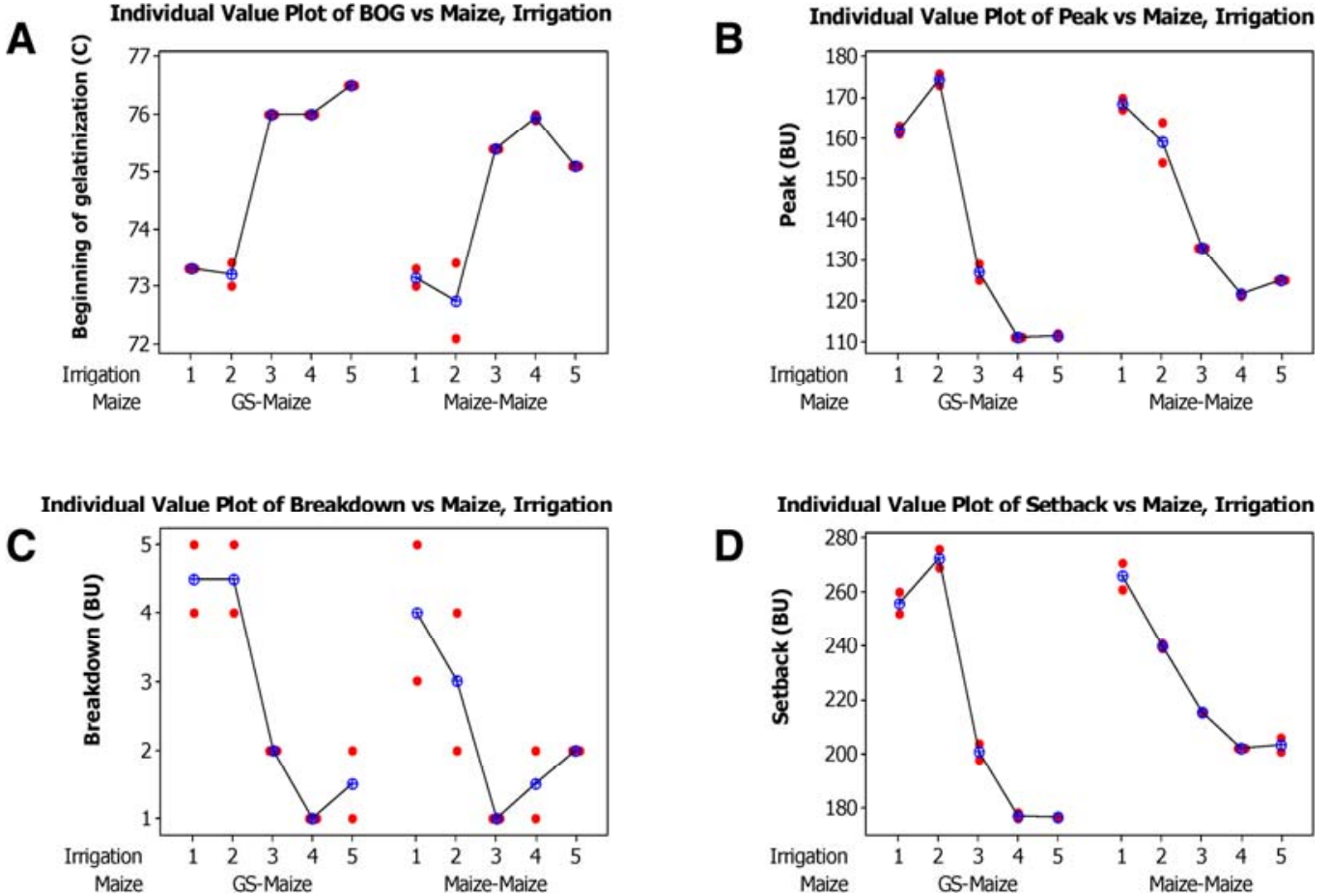

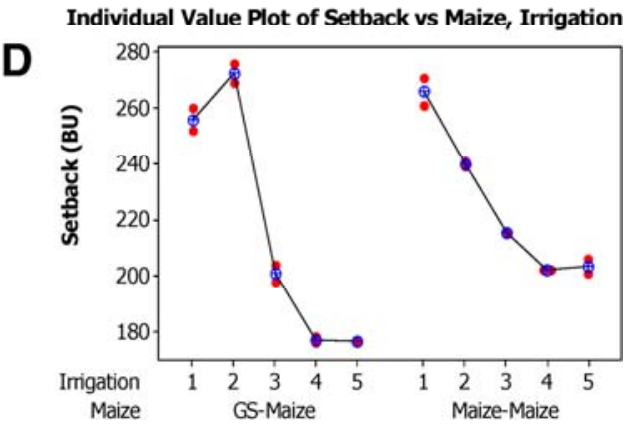

Fig. 6. Starch pasting properties for maize grown in different rotations and irrigation levels (two-way ANOVA; $P<0.05$ ). A, Beginning of gelatinization (BOG); B, peak viscosity; C, breakdown viscosity; and $\mathbf{D}$, setback viscosity $(\bullet=$ two observations; $\oplus=$ mean value). Irrigation level: $1=$ highest and 5 = lowest. GS = grain sorghum; see Table I for a full description of the crop rotations 
78.7, and $84.8-88.2^{\circ} \mathrm{C}$, respectively, and for maize-maize samples they were $70.8-72.4,75.9-78.3$, and $83.8-87.5^{\circ} \mathrm{C}$, respectively. The DSC results showed that starch gelatinization onset, peak, and conclusion temperatures of the maize samples treated with low irrigation levels were significantly higher than in samples treated with high irrigation levels (Fig. 5). High transition temperatures resulted from a high degree of crystallinity, which made the starch granules more resistant to starch gelatinization and required more energy to initiate it (Barichello et al 1990). Lower gelatinization temperature means easier enzymatic hydrolysis and higher fermentation efficiency (Wu et al 2008). Amylases are easily inactivated by heat; if the temperature increases, the enzyme may be inactivated, which leaves the starch hydrolysis process incomplete. Singh et al (2008) reported the relationship between starch granule sizes and transition temperatures in wheat grain. More research is needed to investigate the effect of maize

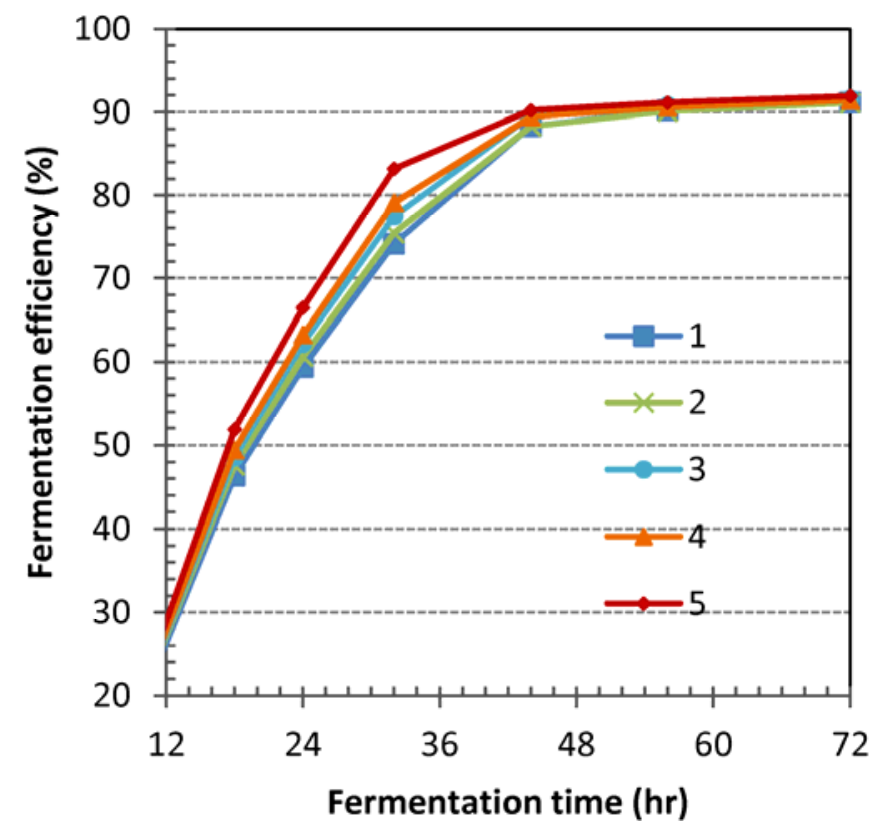

Fig. 7. Relationship between fermentation efficiency and fermentation time among 20 maize samples from five different irrigation levels $(1=$ highest and $5=$ lowest).

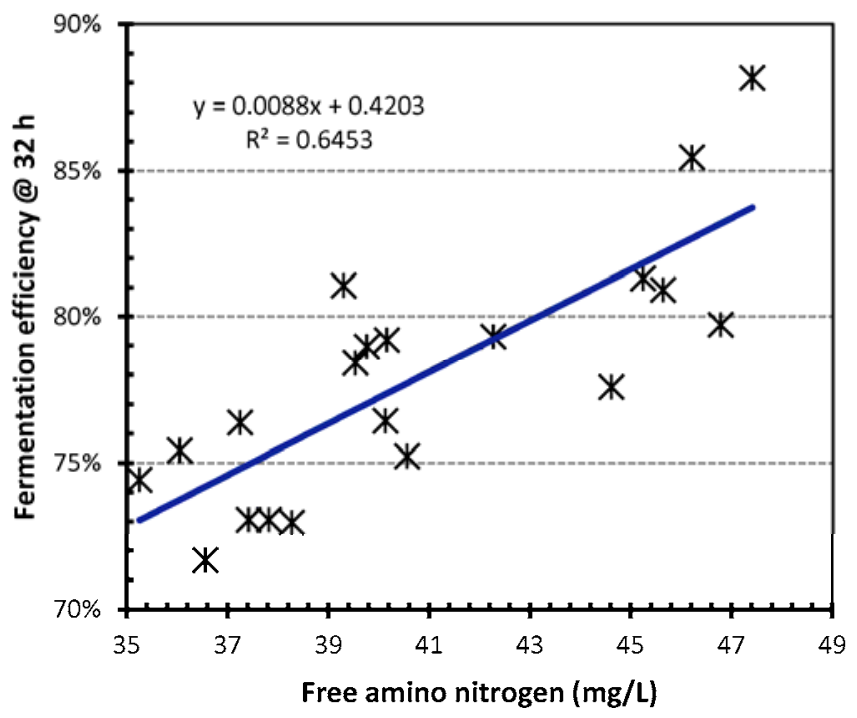

Fig. 8. Linear correlation between free amino nitrogen content $(\mathrm{mg} / \mathrm{L})$ in 20 original maize samples and fermentation efficiency after $32 \mathrm{~h}$ of fermentation. starch granule sizes on the transition temperatures. $\Delta H_{\text {gel }}$ of GSmaize samples ranged from 8.11 to $11.32 \mathrm{~J} / \mathrm{g}$, and maize-maize samples ranged from 6.03 to $8.29 \mathrm{~J} / \mathrm{g}$. $\Delta H_{\text {gel }}$ from all maize samples increased as irrigation level decreased. $\Delta H_{\text {gel }}$ reflected the loss of double-helical order (Cooke and Gidley 1992), and the variations in $\Delta H_{\text {gel }}$ represented differences in bonding forces between the double helices that form the amylopectin crystallites (McPherson and Jane 1999). $\Delta H_{\text {gel }}$ was observed to be positively correlated with $T_{\mathrm{o}}, T_{\mathrm{p}}$, and $T_{\mathrm{c}}$, which agreed with results reported by Sandhu and Singh (2007).

Micro Visco-Amylo-Graph-U starch pasting profiles of maize samples treated with low irrigation levels showed a higher pasting temperature, lower peak viscosity, and lower setback viscosity than maize samples treated with high irrigation levels (Table V and Fig. 6). Taylor et al (1997) reported similar results that sorghums grown under supplementary irrigation had higher peak pasting viscosity and setback viscosity than those produced under rainfed conditions. The beginning of pasting temperature is defined by the initial increase in viscosity and is higher than the gelatinization onset temperature, meaning the starch particles are gelatinized before the viscosity begins to increase (Liang and King 2003). Setback is a process that occurs during cooling in which the starch molecules start to reorder and subsequently form a gel structure. Lower setback values are indicative of slower rates of starch retrogradation (Varavinit et al 2003). Starch peak viscosity and setback viscosity were negatively $(P<0.001)$ correlated with fermentation efficiency.

\section{Effects on Fermentation Efficiency and Ethanol Yield}

Deficit irrigation had a negative impact on ethanol yield (Fig. 2C). The maize with low irrigation yielded about $4.0 \%$ less ethanol (44.14 mL/100 g of maize) than the maize with higher irrigation (45.92 mL/100 $\mathrm{g}$ of maize) (Table IV). Current technologies allow for $44.88 \mathrm{~mL} / 100 \mathrm{~g}$ of maize (2.8 gallons/bushel) of ethanol from maize by the dry-grind process (Bothast and Schlicher 2005). The final fermentation efficiency (after a $72 \mathrm{~h}$ process) of GS-maize samples ranged from 91.18 to $92.48 \%$, and maizemaize samples ranged from 90.96 to $91.68 \%$ (Table IV). No significant differences were found for fermentation efficiency among different samples (Fig. 2D). By monitoring the changes in conversion efficiency through the whole $72 \mathrm{~h}$ fermentation process, the dynamics in the process of reaching their final efficiencies were quite different (Fig. 7). Maize samples from the low irrigation level (low starch contents) had obviously higher conversion efficiency (maximum of 10\% higher) than samples from the high

TABLE VI

Chemical Composition of Distillers Dried Grain with Solubles from Maize Samples $(\%, d b)^{y}$

\begin{tabular}{lccccc}
\hline & \multicolumn{5}{c}{ Chemical Composition $(\%, \mathbf{d b})$} \\
\cline { 2 - 6 } $\begin{array}{l}\text { Irrigation } \\
\text { Level }\end{array}$ & $\begin{array}{c}\text { Total } \\
\text { Starch }\end{array}$ & $\begin{array}{c}\text { Crude } \\
\text { Protein }\end{array}$ & $\begin{array}{c}\text { Crude } \\
\text { Fat }\end{array}$ & $\begin{array}{c}\text { Crude } \\
\text { Fiber }\end{array}$ & Ash \\
\hline GS-maize & & & & & \\
1 & $0.96 \mathrm{a}$ & $30.36 \mathrm{~d}$ & $9.73 \mathrm{a}$ & $3.94 \mathrm{a}$ & $5.16 \mathrm{a}$ \\
2 & $0.94 \mathrm{a}$ & $30.44 \mathrm{~d}$ & $10.09 \mathrm{a}$ & $4.40 \mathrm{a}$ & $5.01 \mathrm{a}$ \\
3 & $1.01 \mathrm{a}$ & $32.86 \mathrm{~b}$ & $9.69 \mathrm{a}$ & $4.78 \mathrm{a}$ & $4.93 \mathrm{a}$ \\
4 & $0.81 \mathrm{a}$ & $33.78 \mathrm{a}$ & $9.32 \mathrm{a}$ & $3.91 \mathrm{a}$ & $4.70 \mathrm{a}$ \\
5 & $0.80 \mathrm{a}$ & $32.98 \mathrm{~b}$ & $9.10 \mathrm{a}$ & $4.40 \mathrm{a}$ & $5.27 \mathrm{a}$ \\
Maize-maize & & & & & \\
1 & $0.95 \mathrm{a}$ & $31.02 \mathrm{~cd}$ & $9.88 \mathrm{a}$ & $4.76 \mathrm{a}$ & $4.96 \mathrm{a}$ \\
2 & $0.92 \mathrm{a}$ & $31.20 \mathrm{c}$ & $9.62 \mathrm{a}$ & $3.90 \mathrm{a}$ & $4.80 \mathrm{a}$ \\
3 & $1.02 \mathrm{a}$ & $33.08 \mathrm{~b}$ & $9.48 \mathrm{a}$ & $3.90 \mathrm{a}$ & $4.62 \mathrm{a}$ \\
4 & $0.88 \mathrm{a}$ & $33.80 \mathrm{a}$ & $9.48 \mathrm{a}$ & $3.92 \mathrm{a}$ & $4.89 \mathrm{a}$ \\
5 & $0.85 \mathrm{a}$ & $32.74 \mathrm{~b}$ & $9.18 \mathrm{a}$ & $4.16 \mathrm{a}$ & $5.00 \mathrm{a}$ \\
\hline
\end{tabular}

${ }^{y}$ Means in the same column followed by different letters indicate significant differences $(P<0.05)$.

${ }^{\mathrm{z}}$ Levels: $1=$ high and $5=$ low. GS $=$ grain sorghum; see Table I for a full description of the crop rotations. 
irrigation level (high starch contents), which we observed during the first 36 h (Fig. 7). Samples with lower starch contents would have higher conversion efficiency if the same amount of yeast were put into the fermentation broths and the inoculated yeast converted sugar to ethanol at a similar rate. Another important factor that may affect the fermentation efficiency is FAN content. This research determined that initial FAN content was significantly affected by irrigation level; it increased as irrigation level decreased (Fig. 2E). A positive linear relationship $\left(r^{2}=0.645\right)$ was found between the initial FAN contents and fermentation efficiency after $32 \mathrm{~h}$ of fermentation (Fig. 8), whereas no linear relationship was found between the initial FAN contents and fermentation efficiency after $72 \mathrm{~h}$. Initial FAN content of samples is a crucial nutrient to yeast cell growth at the early stage of the fermentation process. The higher FAN contents resulted in a faster fermentation process, which was similar to several previous studies on sorghum samples (Yan et al 2009, 2010, 2011; Wu et al 2010) and wheat samples (Casey et al 1984). Sufficient yeast nutrients were put in the tested samples that almost all the sugars were converted into ethanol; therefore, the final fermentation efficiency among samples was close.

\section{Chemical Composition of Distillers Dried Grains with Solubles}

Distillers dried grains with solubles (DDGS) is a by-product of the ethanol production process and is a high-nutrient feed for the livestock industry. Protein, fat, and fiber are the main remaining nutrients used for livestock feed. The nutritional composition is critical to farmers because it determines the sale price of DDGS. Table VI shows the major components of maize DDGS. Residual starch contents were similar between high-irrigation-level and lowirrigation-level maize samples. As discussed earlier, it was because sufficient yeast nutrients had been put in the tested samples and almost all the sugars were converted to ethanol; therefore, the final conversion efficiency was not significantly different. DDGS with low irrigation levels had higher crude protein content, which means better quality for livestock feed uses. There were no differences in crude fat, fiber, and ash contents among all DDGS samples.

\section{CONCLUSIONS}

Deficit irrigation had significant effects on grain physical properties, chemical composition, and ethanol yield. Maize kernel weight, density, and breakage susceptibility decreased as irrigation level decreased. Starch contents in maize samples at the low irrigation level were lower than those at the high irrigation level and gave the lowest ethanol yield. The FAN content increased as irrigation level decreased and greatly affected fermentation efficiency at the early stage (the first $36 \mathrm{~h}$ ), which had a positive linear correlation with $32 \mathrm{~h}$ fermentation efficiency. The starch granule size was affected by irrigation level, and the starch-protein matrix in the grain may affect fermentation efficiency. Crop rotation had significant effects on grain test weight and true density. More research needs to be done on the effect of crop rotation on grain qualities in the future.

\section{ACKNOWLEDGMENTS}

This research was supported in part by the Ogallala Aquifer Program, a consortium between USDA Agricultural Research Service, Kansas State University, Texas AgriLife Research, Texas AgriLife Extension Service, Texas Tech University, and West Texas A\&M University.

\section{LITERATURE CITED}

AACC International. Approved Methods of Analysis, 11th Ed. Method 08-03.01. Ash-Rapid (2-hour, 600 ) method. Approved April 13, 1961. Method 30-20.01. Crude fat in grain and stock feeds. Approved April 13, 1961. Method 55-10.01. Test weight per bushel. Approved April 13, 1961. Method 55-20.01. Corn breakage susceptibility. Ap- proved November 11, 1981. Method 76-13.01. Total starch assay procedure (Megazyme amyloglucosidase/ $\alpha$-amylase method). Approved November 8, 1995. Available online only. AACCI: St. Paul, MN.

AOAC. 1999. Official Methods of Analysis of AOAC International, 18th Ed. Methods 920.39, 942.05, and 990.03. AOAC International: Gaithersburg, MD.

ANKOM Technology. 2006. Method 10. Based on AOCS Approved Procedure Ba $6 \mathrm{a}-05$.

Ayana, M. 2011. Deficit irrigation practices as alternative means of improving water use efficiencies in irrigated agriculture: Case study of maize crop at Arba Minch Ethiopia. Afr. J. Agric. Res. 6:226-235.

Barichello, V., Yada, R. Y., Coffin, R. H., and Stanley, D. W. 1990. Low temperature sweetening in susceptible and resistant potatoes: Starch structure and composition. J. Food Sci. 55:1054-1057.

Bauer, P. J., and Carter, P. R. 1986. Effect of seeding date, plant density, moisture availability, and soil nitrogen fertility on maize kernel breakage susceptibility. Crop Sci. 17:362-366.

Bothast, R. J., and Schlicher, M. A. 2005. Biotechnological processes for conversion of corn into ethanol. Appl. Microbio. Biotech. 67:19-25.

Bryant, R. J., Anders, M., and McClung, A. M. 2009. Effect of cultural management practices on grain quality of two rice cultivars. Cereal Chem. 86:405-409.

Calderón-Chinchilla, V. R., Hernández-Valle, M., Mason, S. C., and Rooney, L. W. 2008. Influencia del nitrógeno en la calidad del grano de sorgo en El Salvador (Influence of nitrogen on sorghum grain quality in El Salvador). Agron. Mesoam. 19:47-56.

Casey, G. P., Magnus, C. A., and Ingledew, W. M. 1984. High-gravity brewing: Effects of nutrition on yeast composition, fermentative ability, and alcohol production. Appl. Environ. Microbiol. 83:639-646.

Cooke, D., and Gidley, M. J. 1992. Loss of crystalline and molecular order during starch gelatinization-Origin of the enthalpic transition. Carbohydr. Res. 227:103-112.

Daniel, C., and Triboï, E. 2002. Changes in wheat protein aggregation during grain development: Effects of temperatures and water stress. Eur. J. Agron. 16:1-12.

European Brewery Convention (EBC). 1987. Free amino nitrogen-ninhydrin colorimetric method. Pages E141-142 in: Analytica-EBC, 4th Ed. Braurei Getraenke Rundschau: Zurich, Switzerland.

Fereres, E., and Soriano, M. A. 2007. Deficit irrigation for reduced agricultural water use. J. Exp. Bot. 58:147-159.

Griess, J. K., Mason, S. C., Jackson, D. S., Galusha, T. D., Yaseen, M., and Pedersen, J. F. 2010. Environment and hybrid influences on food grade sorghum grain yield and hardness. Crop Sci. 50:1480-1489.

Guttieri, M. J., Ahmad, R., Stark, J. C., and Souza, E. 2000. End-use quality of six hard red spring wheat cultivars at different irrigation levels. Crop Sci. 40:631-635.

Heng, L. K. 2002. Deficit Irrigation Practices. Water reports, no. 22. Food and Agriculture Organization of the United Nations: New York, NY.

Kaye, N. M., Mason, S. C., Jackson, D. S., and Galusha, T. D. 2007. Crop rotation and soil amendment alters sorghum grain quality. Crop Sci. 47:722-729.

Kirda, C. 2002. Deficit irrigation scheduling based on plant growth stages showing water stress tolerance Pages 3-10 in: Deficit Irrigation Practices. Water reports, no. 22. Food and Agriculture Organization of the United Nations: New York, NY.

Kirda, C., Topcu, S., Kaman, H., Ulger, A. C., Yazici, A., Certin, M., and Derici, M. R. 2005. Grain yield response and N-fertilizer recovery of maize under deficit irrigation. Field Crops Res. 93:132-141.

Klocke, N. L., Payero, J. O., and Schneekloth, J. P. 2007. Long-term response of corn to limited irrigation and crop rotation. Trans. ASABE 50:2117-2124.

Klocke, N. L., Currie, R. S., Tomsicek, D. J., and Koehn, J. W. 2011. Corn yield response to deficit irrigation. Trans. ASABE 54:931-940.

Kniep, K. R., and Mason, S. C. 1989. Kernel breakage and density of normal and opaque-2 maize grain as influenced by irrigation and nitrogen. Crop Sci. 29:158-163.

Lacerenza, J. A., Martin, J. M., Talbert, L. E., Lanning, S. P., and Giroux, M. J. 2008. Relationship of ethanol yield to agronomic and seed quality characteristics of small grains. Cereal Chem. 85:322-328.

Liang, X., and King, J. M. 2003. Pasting and crystalline property differences of commercial and isolate rice starch with added amino acids. J. Food Sci. 68:832-838.

McPherson, A. E., and Jane, J. 1999. Comparison of waxy potato with other root and tuber starches. Carbohydr. Polym. 40:57-60.

Miller, A. N., and Ottman, M. J. 2010. Irrigation frequency effects on 
growth and ethanol yield in sweet sorghum. Agron. J. 102:60-70.

Pandey, R. K., Maranville, J. W., and Admou, A. 2000. Deficit irrigation and nitrogen effects on maize in a Sahelian environment: I. Grain yield and yield components. Agric. Water Manage. 46:1-13.

Paulsen, M. R., and Hill, L. D. 1985. Corn quality factors affecting dry milling performance. J. Agric. Eng. Res. 31:255-263.

Paulsen, M. R., Hill, L. D., White, D. G., and Sprague, G. F. 1983. Breakage susceptibility of corn-belt genotypes. Trans ASAE 26:1830-1836.

Peplinski, A. J., Paulsen, M. R., and Bouzaher, A. 1992. Physical, chemical, and dry-milling properties of corn of varying density and breakage susceptibility. Cereal Chem. 69:397-400.

Pomeranz, Y., Martin, C. R. Traylor, D. D., and Lai, F. S. 1984. Corn hardness determination. Cereal Chem. 61:147-150.

Pomeranz, Y., Hall, G. E., Czuchajowska, Z., and Lai, F. S. 1986. Test weight, hardness, and breakage susceptibility of yellow dent corn hybrids. Cereal Chem. 63:349-351.

Quiroga, D., Fernandez-Haddad, Z., and Iglesias, A. 2011. Crop yields response to water pressures in the Ebro basin in Spain: Risk and water policy implications. Hydrol. Earth Syst. Sci. 15:505-518.

Sandhu, K. S., and Singh, N. 2007. Some properties of corn starches II: Physicochemical, gelatinization, retrogradation, pasting and gel textural properties. Food Chem. 101:1499-1507.

Singh, S., Singh, G., Singh, P., and Singh, N. 2008. Effect of water stress at different stages of grain development on the characteristics of starch and protein of different wheat varieties. Food Chem. 108:130-139.

Taylor, F. R. N., Dewar, J., Taylor, J., and von Ascheraden, R. F. 1997. Factors affecting the porridge-making quality of South African sorghums. J. Sci. Food Agric. 73:464-470.

Thomas, K. C., Hynes, S. H., and Ingledew, W. M. 1996. Practical and theoretical considerations in the production of high concentrations of alcohol by fermentation. Process Biochem. 31:321-331.

Tognetti, R., d'Andria, R., Lavini, A., and Morelli, G. 2006. The effect of deficit irrigation on crop yield and vegetative development of Olea europaea L. (cvs. Frantoio and Leccino). Eur. J. Agron. 25:356-364.

U.S. Department of Agriculture (USDA). 2012. World Agricultural Supply and Demand Estimates. Available at: www.usda.gov/oce/commodity/ wasde/latest.pdf

U.S. Grains Council. 2011. Annual report. Available at: www.statista.com/ printstat/203245/

Varavinit, S., Shobsngob, S., and Warunee, V. 2003. Effect of amylose content on gelatinization, retrogradation and pasting properties of different cultivars of Thai rice. Starch/Stärke 55:410-415.

Weightman, R. M., Millar, S., Alava, J., Foulkes, M. J., Fish, L., and Snape, J. W. 2008. Effects of drought and the presence of the 1BL/1RS translocation on grain vitreosity, hardness and protein content in winter wheat. J. Cereal Sci. 47:457-468.

Wolf, M. J., Buzan, C. L., MacMasters, M. M., and Rist, C. E. 1952. Structure of the mature corn kernel. I. Gross anatomy and structural relationships. Cereal Chem. 29:321-333.

Wu, X., Zhao, R., Wang, D., Bean, S. R., Seib, P. A., Tuinstra, M. R., Campbell, M., and O'Brien, A. 2006. Effects of amylose, corn protein, and corn fiber contents on production of ethanol from starch-rich media. Cereal Chem. 83:569-575.

Wu, X., Zhao, R., Liu, L., Bean, S., Seib, P. A., McLaren, J., Madl, R., Tuinstra, M., Lenz, M., and Wang, D. 2008. Effects of growing location and irrigation on attributes and ethanol yields of selected grain sorghums. Cereal Chem. 85:495-501.

Wu, X., Jampala, B., Robbins, A., Hays, D., Yan, S., Xu, F., Rooney, W., Peterson, G., Shi, Y., and Wang, D. 2010. Ethanol fermentation performance of grain sorghums (Sorghum bicolor) with modified endosperm matrices. J. Agric. Food Chem. 58:9556-9562.

Yan, S., Wu, X., MacRitchie, F., and Wang, D. 2009. Germinationimproved ethanol fermentation performance of high-tannin sorghum in a laboratory dry-grind process. Cereal Chem. 86:597-600.

Yan, S., Wu, X., Dahlberg, J., Bean, S. R., MacRitchie, F., Wilson, J. D., and Wang, D. 2010. Properties of field-sprouted sorghum and its performance in ethanol production. J. Cereal Sci. 51:374-380.

Yan, S., Wu, X., Bean, S. R., Pedersen, J. F., Tesso, T., Chen, Y. R., and Wang, D. 2011. Evaluation of waxy grain sorghum for ethanol production. Cereal Chem. 88:589-595.

[Received July 6, 2012. Accepted March 19, 2013.] 